\title{
Semiotic behavior in Luke and John
}

\author{
Richard L Rohrbaugh ${ }^{1}$ \\ Lewis \& Clark College, Portland, USA \\ Research Associate: Department of New Testament \\ University of South Africa
}

\begin{abstract}
As socio-linguists have demonstrated, communication is a behavior that follows socially generated and commonly understood rules for how messages are to be produced and received. Moreover, this semiotic process constitutes a complex and pervasive mechanism of social control - even if it is not often recognized as such. It is thus possible to ask how meaning is actually created and acknowledged in a given society. Who determines the rules? How are rules maintained, modified or subverted? Such questions focus our attention on who is producing and receiving what types of meaning and whose interests are being served by the way the process itself is constructed. As a case in point, we shall compare the semiotic process in the Lukan and Johannine presentations of Jesus in order to ask what these processes imply for social relations in the communities that produced them.
\end{abstract}

\section{INTRODUCTION}

Given the individualistic sensibilities of Western culture it is rather easy to think about authors and texts as if one is simply the product of the other. But semiosis - the process of producing and exchanging meaning - is in fact extremely interactive behavior and therefore inescapably social. Thus questions about the nature of this social process immediately come to the fore.

In what way is meaning actually created and acknowledged? What are the rules for its production? Who determines the rules? How are rules maintained, modified or subverted? How do particular styles, genres, narrative choices or other literary strategies

\footnotetext{
1 Paper presented at the International Context Group Meeting at the University of Pretoria, June 2001. Prof Dr Richard L Rohrbaugh visited South Africa as Research Associate of Prof Dr Eugene J Botha, Department of New Testament, Faculty of Theology and Religion, Unisa.
} 
reflect or maintain dominant social interests? Such questions focus our attention on who is producing and receiving what types of meaning and whose interests are being served by the way the process itself is constructed. As a case in point we shall compare the semiotic process in the Lukan and Johannine presentations of Jesus in order to ask what these processes imply for social relations in the communities that produced them.

\section{THE LOGONOMIC SYSTEM}

As socio-linguists have effectively demonstrated, communication is a behavior that follows socially generated and commonly understood rules for how messages are to be produced and received. Moreover, this complex of rules, often called a "logonomic system" by socio-linguists, constitutes a complex and pervasive mechanism of social control - even if it is not often recognized as such. The rules cannot be either obscure or confusing if communication is to work. Nor can they be arbitrarily or whimsically altered without causing confusion or conflict, though of course precisely that may be the intent of a speaker or writer.

The logonomic system, of course, is part of the socialization process for children and is taught by educators, parents, public figures and peers. The rules are policed by these same social agents, often by coercion, and are reinforced in all sorts of public discourse, including something as formal as the discourse taught in the rhetorical schools or as informal as that heard in the gossip network. Because such rules are part of an ongoing and continuously negotiated social contract, they are always part of an ideological complex that both expresses and reflects specific social relations.

Equally important for our purposes is the fact that logonomic systems can be challenged or resisted by subordinate persons or groups. Anti-languages are an obvious example. So also are off-color jokes in inappropriate settings, or talking during an operatic aria, or calling newly introduced dignitaries by their first names. Semiotic challenges in the form of unexpected speech behaviors are often very subtle, but at the same time can carry heavy freight in terms of meaning.

A simple example is afforded by the way greetings are exchanged in American culture. A handshake and "How are you?" is expected to be followed rather quickly with the response, "Fine, how are you?" But suppose the handshake and initial question are 
followed by a significant pause. The belated "Fine, how are you?" raises immediate suspicion. Is the respondent distracted? Caught off guard? Or does the pause indicate hostility? Perhaps the respondent is Algonquin, a culture in which rapid response is deemed impolite. Such "marked speech," as Muriel Saville-Troike calls it, speech in which the logonomic indicators are unusual or unexpected, is difficult for outsiders in any society to catch and understand.

A corollary of all this is that when systems of domination are being challenged, logonomic systems are likely to be challenged as well. Since such systems are the result of long and continuous negotiation between elite and non-elite, and since in large measure they reflect the elite view of the world, accommodation to the logonomic system by subordinate groups often mirrors accommodation to the larger social contract. And by the same token where structures of domination are undergoing challenge, logonomic systems are often a key point at which social conflict first emerges. An obvious case in point: it is anti-societies that produce anti-languages.

It is important here to recognize that rules for the production and reception of meaning, even informal ones, are the result of an on-going process of negotiation and social change - often over long periods of time. They are a social product, a group product, and often represent group interests in the ongoing life of the social contract. Moreover, since they seek to prescribe and control behavior, they are forms of power. As Antonio Gramsci has shown in his discussion of the way hegemonic structures are produced in a society, there is an on-going struggle between intellectuals who represent various social groups, including even peasants, over the proper way to represent the world. Thus every communication, every exchange of meaning, is an event, however tiny, in an on-going struggle that involves a subtle negotiation of power.

Of course a logonomic system is effective only insofar as some group is able to articulate and enforce it - whether through informal persuasion, educational processes, peer sanction, class envy, or whatever. It becomes part of an ideological complex that the dominant think is the way things should be and the dominated think is the way things are. Speech rules, both formal and informal, are thus examples of group enforcement of hegemonic patterns of behavior. 


\section{FIRST AND SECOND LEVEL MEANINGS}

Socio-linguists have long recognized that analysis of the rules for the production of meaning requires acknowledging two levels of meaning in every message. Thus firstlevel meaning, content, is always accompanied by additional levels of meaning that are conveyed by style, genre, tone, gesture, facial expressions, touching and the like. Second-level meanings provide indicators for how first-level meanings are to be taken or understood. A joke, for example, should not be taken seriously. Readers have to know the clues that indicate when an author is joking, being sarcastic, using irony or whatever. As Sirach (20:20) puts it, "A proverb from a fool's lips will be rejected, for he does not tell it at the proper time."

Such second-level meanings are deeply embedded in social processes that shape the way authors and speakers make choices about how they wish to say what it is they wish to say. Anger, for example, may be expressed in a cold, controlled, impersonal style, or in a loud, aggressive and emotional manner. The medium is part of the message. Such first and second level meanings often coincide, but of course they can also contradict. Pounding the table while shouting that one is not angry is an obvious case of contradiction. Thus jokes may hide nervousness and excessive bravado may actually signal weakness. As it says in Prov 27:6, "Well meant are the wounds a friend inflicts, but profuse are the kisses of an enemy."

In sum, in examining the strategies of Luke and John for presenting Jesus, we shall look at their use of the logonomic system - the rules for the production of meaning. We shall observe whose rules are being followed, and what social relations are thereby implied. Part of that analysis will involve second-level meanings. Thus it is not just what these writers say, but how they choose to say it that will be the focus of our investigation.

\section{LIMITATIONS}

Before jumping into this look at semiotic process in Luke and John, however, we must acknowledge that this approach has serious limitations. For example, it is obvious that many of the second-level meanings in New Testament discourse are forever lost to the modern world. It is not just that we lack evidence for things like tone of voice, facial 
expressions, rapidity of speech and the like. It is also that being cultural outsiders we have no access to many of the complex indicators that could be used to "mark" speech for an ancient reader. For example, were Jesus' answers to the many questions put to him by antagonists done in rapid-fire fashion? Or were they slow and deliberate? And even more importantly, what would it mean in first-century Palestine to offer rapid-fire as over against deliberate answers? Analysis of logonomics at that level is simply not possible for us.

Similarly, even when authors do offer second-level clues they are often ambiguous or unclear. As Sirach (20:6) puts it, "Some people keep silent because they have nothing to say, while others keep silent because they know when to speak." A good example of ambiguous second-level markers can be found in $\mathrm{Lk}$ 7:38 where a woman weeps and kisses the feet of Jesus. Both the tears and the kisses are second-level indicators. They are meant to inform the reader how to understand the dynamics of the story. But both actions can be read in a variety of ways.

It turns out there is a lot of kissing in the Bible (57 incidents). But its meaning can vary. It can indicate romance (SS 1:2; 7:9; 8:1), seduction (Prov 7:13), deference (Sir 29:5), kinship ties (Gen 27:27; 29:11, 13), fictive kinship ties (Rom 16:16; 1 Cor 16:20; 2 Cor 13:12; 1 Th 5:26), loyalty (1Kgs 19:18; Hos 13:12), friendship (1 Sm 20:41), peace (Ps 85:10), or love (1 Pt 5:14). It can be used to deceive (Prov 27:6), to ingratiate in the hope of gaining a loan (Sir 29:5), or even to betray (Mk 14:44//). It can also involve contact with a number of different body parts. One can kiss the lips (Prov 24:26), the feet (Ps 2:12; Lk 7:38), or the soles of the feet (G Est 13:13). Herodotus (History 1.134) says that among some people kissing certain body parts is a clue to honor relations:

When they meet each other in the streets, you may know if the persons meeting are of equal rank by the following token: if they are, instead of speaking, they kiss each other on the lips. In the case where one is a little inferior to the other, the kiss is given on the cheek; where the difference of rank is great, the inferior prostrates himself upon the ground 
In other words kissing, used as a second -level indicator, can imply certain kinds of social relations that are important to the dynamics of ancient stories, but for us today the meaning of the kissing is not always clear.

Tears can be equally ambiguous. They can indicate grief (Ps 6:6; Is 22:4), joy (Gen 34:4; 45:14, 15), sincerity (2 Kgs 20:5; Is 38:5; Heb 5:7; 12:17), insincerity (Sir 12:16), mourning (Ps 102:9; Sir 38:16; Jn 11:35), complaint (Mal 3:13), humility (Ac 20:19), anguish (2 Cor 2:4), affection (Gen 43:30) or empathy (Job 30:25). They can also provide support for a plea or supplication (Ps 39:12).

When kisses and tears are combined, this same ambiguity appears. Kissing and weeping can indicate joy (Gen 29:11; 33:4; 45:15), sorrow (Rut 1:14), or mourning (Gen 50:1). The woman in Lk 7:38 both weeps and kisses the feet of Jesus. Are these tears of joy? Or of sorrow and repentance? Commentators cannot decide (Fitzmyer 1981:68689). And what about the fact that she kisses Jesus' feet? Should we assume this is status recognition, indicating the woman's humility and Jesus' honor? Or is it a plea for forgiveness? (cf GrEst 8:3). Perhaps it is worship ( $\operatorname{cf}$ Mt 4:9; Ac 10:25)? These secondlevel indicators are not all that clear to us now even when we know that the story is contrasting the woman's behavior with that of the man hosting the dinner.

\section{NARRATIVE CHOICES}

If rules for the production and reception of meaning, including those that employ secondlevel indicators, are often obscure to cultural outsiders, nonetheless some of those in the New Testament remain transparent yet today. One good example can be seen in the choices an author makes regarding the narrative elements or rhetorical strategy to be employed in addressing a particular audience.

One such choice, frequently recognized by socio-linguists, is an author's choice of

genre. Genres are, after all, rules for the production of meaning. As Hodge \& Kress (1988:7) put it, they are "socially prescribed classifications of semiotic form." Because they are socially prescribed, they control the behavior of those who produce texts as well as the expectations of those who receive them. Moreover, the rules for the production of a specific genre not only structure its form, thereby accommodating to audience expectations, they also structure or imply certain social relations among various 
participants in the semiotic process. The business-letter form, for example, implies one type of social relationship between author and recipient; a personal-letter format suggests quite another. Court records, text-books, nursery rhymes, jokes, gossip, and a host of other forms all imply, indeed depend upon, specific social relations between producer and receiver for the production and reception of meaning.

Other narrative elements might equally well be understood as a response to rules in a production or reception regime. In honor-shame societies, for example, a response is expected whenever any kind of challenge is offered. A missing response speaks volumes, as does one that is inappropriate or ill timed. In addition, since honor that goes unrecognized is of no value whatsoever, readers of an ancient narrative would probably expect an author to provide notice of story-audience approval whenever a character in a story had been given a grant of honor. Ancient audiences would surely notice if these kinds of second-level indicators were missing. Thus narrative elements, chosen by an author as part of a rhetorical strategy, are good indicators of semiotic behavior and how the rules are or are not being followed.

\section{SEMIOTIC BEHAVIOR IN LUKE AND JOHN}

In order to illustrate what we have been talking about we shall look briefly at the presentation of Jesus in two of the Gospels: Luke and John. Our argument will be that Luke accepts the logonomic system of elite Greco-Roman society and assumes his readers will do the same. Certain social relations thereby implied. By contrast, the Johannine community rejects the dominant society and therefore it is not surprising that one of the places this conflict emerges is in its response to the socially prescribed semiotic behaviors that dictate how you present the hero of a story.

\subsection{Luke: Moving Jesus up the honor scale}

The degree to which Luke has bought into the semiotic process of elite Greco-Roman society is quite astonishing. It can be clearly seen in the choices Luke makes about how to commend Jesus to his reading audience. Among the literate elite of the Roman world honor was a core social value. Thus for Luke, the village-artisan Jesus of the Gospel of Mark (6:3), who lacked significant standing on the scale of honor, was hardly suitable for 
his version of the story. Luke needed to take dramatic action. By any measure, the lengths to which he goes to move Jesus up the honor scale, and thereby make him acceptable to elite readers, are truly extraordinary.

In attempting to do this Luke had two basic options. One would be to address the ascribed honor status of Jesus, the honor gained from his position at birth. The other would be to address his acquired honor status, the honor he gained in the course of his public career. Elite audiences of course would expect ascribed and acquired honor to go hand in hand, hence in order to leave no doubt about the matter Luke makes bold use of both options. While we cannot describe his strategy comprehensively, a survey of key data will make clear that Luke knows how to make and exchange meaning in the elite world of Roman society.

\subsubsection{Ascribed honor}

We begin with ascribed honor and Luke's use of a socially prescribed semiotic form: the encomium. There is no better example of a logonomic system at work than the wellknown instructions offered in the ancient Greek rhetorical schools for writing a piece in praise of someone. Since these instructions from the progymnasmata for writing an encomium are well known, a brief summary of their provisions will suffice. Hermogenes (Rhetores Graeci II.14.8-15.5) instructs his students to begin with the subject's origin and birth. They are to speak of "race, as the Greek, a city, as Athens, a family as the Alcmaeonidae."

This of course is exactly what Luke does in his story of Jesus' origins. First, he provides a royal genealogy tracing Jesus' origins back to God (Lk 3:23-38). In antiquity lineage was not only a source of pride, but also a device for self-aggrandizement (Hood 1961:3-8). It was a claim to authority, to place, to political or civil rights, to various social roles and even the right to speak. To have a written pedigree, and especially a long one, was a mark of honor. Luke provides the longest genealogy possible.

Menander Rhetor (Treatise II 369.17-370.10) joins the chorus by saying that one of the first things to be done is to praise the city from which the subject comes, because honor is ascribed to those born in an honorable city. Luke does this too. He reports Jesus' birth in a "royal" city, the city of David ( $\operatorname{Lk} 2: 4,11)$. While Bethlehem hardly 
qualifies as a "city" in any real sense, neither Luke nor his readers seem to know that. Thus Luke offers it as a place that can produce the likes of David and, by implication, a Jesus whose ascribed honor is of a similar kind.

Hermogenes adds that the writer should then describe "what marvelous things befell at birth, as dreams or signs or the like." Luke once again follows the instructions, reporting on angelic appearances and heavenly songs (Lk 2:9-14). Quintilian (Inst Orat 3.7.10-18) instructs a writer to note things that happened prior to the birth such as prophecies "foretelling future greatness". Luke provides these as well. One message comes from heaven, from an angel (Lk 1:26-38), the other from Zechariah who spoke when filled with the Holy Spirit (Lk 1:67-73). The angel declares Jesus' royalty (Lk 1:32) while Zechariah asserts that he is of the house of David and will be nothing less than the "prophet of the Most High" (Lk 1:76). For the Jesus who started as a village artisan in Mark, the entire social spectrum has just been traversed. His ascribed honor is thus secure.

\subsubsection{Acquired honor}

Luke's claims about Jesus' acquired honor are equally pretentious. While there are a number of means by which Luke seeks to demonstrate the acquired honor of Jesus (titles, skill at repartee, ability to confound questioners, etc) we shall concentrate on the matter of public reputation since it is reputation that is the necessary public validation of an acquired honor status. No doubt the frequency with which Luke reports public acknowledgment of Jesus' growing reputation seems unnecessary to modern readers who usually pass over such notices without a second glance. Our logonomic system creates no such expectation. But these reports would have been exactly what ancient readers expected. As Aristotle puts it, "A good reputation consists in being considered a man of worth by all ...."

The number of times Luke reports public praise of Jesus is truly amazing. Simeon praises the child in the temple ( $\operatorname{Lk} 2: 25-35)$. Anna does the same to all who will listen (Lk 2:38). His parents are amazed at his understanding ( $L k$ 2:47). Luke tells us he increased in (divine and) human favor (Lk 2:52). John the Baptist publicly places Jesus higher than himself on the honor scale (Lk 3:16). A divine voice praises him and 
acknowledges his genealogy ( $\operatorname{Lk} 3: 22$ ). The gossip network spreads his fame in the surrounding country and he is praised by everyone (Lk 4:14-15). All are amazed at him in the synagogue of Nazareth ( $\operatorname{Lk} 4: 22)$. In Capernaum they are astounded at his teaching (Lk 4:32) and his power over demons ( $\operatorname{Lk} 4: 36$ ). Reports of him reach every place in the region (Lk 4:37). Word of his healing spreads abroad (Lk 5:15). He amazes onlookers by healing a paralytic and everyone is filled with awe (Lk 5:26). His reputation even reaches a high-ranking Roman officer (Lk 7:3). After raising the son of the widow of Nain, Jesus is praised as a prophet (Lk 7:16), and his fame spreads throughout the region (Lk 7:17).

In Lk 7:18 the reputation of Jesus reaches John the Baptist who sends disciples to inquire. They are asked to report what they have seen and heard (Lk 7:22). After Jesus forgives a woman of the city, those at the table with him are taken aback by what they have witnessed ( $\operatorname{Lk} 7: 49)$. His disciples acknowledge that he commands even the wind and water (Lk 8:25). When Jesus heals a demoniac in the country of the Gerasenes, the swineherds tell everyone and the report spreads fear in the area (Lk 8:37). Jairus, a member of the elite, falls at Jesus feet (a gesture of inferiority) to beg for his daughter's life. When she is healed he is "astounded" (Lk 8:56).

Luke reports that the reputation of Jesus even reaches the royal court (Lk 9:9). The crowds near Bethsaida also hear of him (Lk 9:11). Divine approval in the hearing of his disciples is again given to Jesus on the mountain ( $\operatorname{~}$ 9:35). A great crowd is astounded at the healing of an epileptic boy, and indeed at everything he was doing (Lk 9:43). In Lk 10:17 even demons submit to his name (honor, reputation). Later, when Jesus is casting a demon out of a mute person, the crowd is again amazed (Lk 11:14), though opponents look for an alternate explanation for what is happening (Lk 11:15). In Lk 11: 27 a woman publicly praises Jesus' mother (hence Jesus by implication) by calling her "honored."

Luke's hyperbole in Lk 12:1 ("thousands," "trampled one another") implies a growing reputation as well. Later in Lk 13:17 we are told that Jesus' enemies have been "put to shame" while the entire crowd rejoices at what he does. "All" the people praise him when he heals a beggar in Lk 18:43. When Jesus rides into Jerusalem to the praise of a multitude of disciples, Pharisees ask Jesus to quiet them. But Jesus replies that even the 
stones would cry out if the crowd did not (Lk 19:40). Later, when he teaches in the temple, we are told that the people were "spellbound" by what they heard (Lk 19:48). Having decisively confounded those who publicly challenge him over payment of taxes, the narrator reports that even his opponents were amazed (Lk 20:26). And finally, in Lk 21:38 we are told that people will even get up early in the morning just to listen to him in the temple.

Given the fact that all of these notices are constructed by the narrator, it is safe to say that concern for acquired honor, for public reputation, is critical to Luke's rhetorical strategy. Of the 37 examples cited above, Luke has added 22 to Mark's story of Jesus. Would a modern writer write this way? Unlikely. Would an ancient Mediterranean writer? Yes, indeed, especially if writing for those who know the rules and therefore expect acknowledgement of public reputation as the justification for any claims the story makes.

\subsection{John: Leaving the earthly Jesus where he is}

When we come to the Gospel of John we enter a different world. That is true not only in terms of the Gospel 's content, but also in terms of its second-level indicators. It does not emerge from the peasant world of Mark. Nor is it from the sophisticated urban worlds of Matthew and Luke. Its Jesus displays neither special identification with the poor nor the high level of honor worthy of elite urban readers. As we shall see, something else drives John's unique portrait of Jesus.

John is almost certainly a Galilean Gospel recounting the Jesus story for a mixed (Galilean, Samaritan, Gentile) community of Jesus' followers (Brown). Moreover, this community was likely what sociolinguist M A K Halliday calls an "anti-society," that is, a group that exists within a dominant society but as a "conscious alternative to it" (Halliday 1976:570). It was an alienated group that had been pushed (or withdrawn) to the social margins where it stood as a protest to the values of the larger society (Malina \& Rohrbaugh 1998).

The scope and depth of this alienation is evident in the language of the Gospel

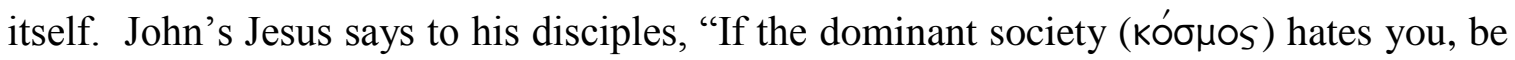
aware that it hated me before it hated you. If you belonged to the society, the society 
would love you as its own. Because you do not belong to the society, but I have chosen you out of the society - therefore the society hates you" (Lk 15:18-19; my translation).

This is tough talk. Yet it accurately conveys the temper of the group's relations with outsiders. As the story makes clear, the hostility of the Johannine group was especially aimed at Judeans. Members of John's group saw the larger Judean society as hostile to Jesus and therefore hostile to themselves. John's Jesus calls Judeans children of the devil ( $\operatorname{Lk} 8: 44$ ), and they respond by claiming he is either a Samaritan or possessed by demons (Lk 8:48). Obviously this is a group whose relations with the dominant society have gone rather sour.

It is in the midst of this social conflict that John locates the earthly Jesus. We argued earlier that where systems of domination are being challenged, logonomic systems are often a key point at which social conflict first emerges. In his presentation of Jesus, John has this on full display. Like Luke, John defends Jesus vigorously (attacking his opponents with equal vigor), but in doing so he makes no claim for the honor of the earthly Jesus. There is no attempt here to push Jesus up the scale. Unashamedly, almost defiantly, John admits that the earthly Jesus is nothing.

A key issue in John's Gospel is where Jesus is "from." We have already seen the importance of birth/origin because it determined ascribed honor, public legitimacy and authority. In the instructions of the progynasmata (see above) we were told to pay great attention to birthplace because great people are born in great places. Obviously obscure Galilean villages like Nazareth would not qualify (John has no Bethlehem tradition). As Nathanael puts it, "Can anything good come out of Nazareth?" (Lk 1:46; see also Lk 7:52). Jesus cannot be counted as honorific on the basis of his place of origin.

John is aware of this. In Jn 7, while Jesus is at the Feast of Tabernacles in Jerusalem, in the midst of a tense and potentially dangerous situation, a dispute arises in the crowd about whether Jesus might be the Messiah. Then someone in the crowd shouts, "We know where this man is from ..." (Jn 7:27). Implication: he comes from a place of no account, hence could not be the Messiah. Another speaker puts it squarely: "Surely the Messiah does not come from Galilee does he?" (Jn 7:41). A third speaker reminds everyone that the Scripture foretells a Messiah from Bethlehem, from the house of David the king (Jn 7:42). The result is chaos and a near arrest. 
It is right in the midst of all this that John's Jesus openly admits that his origin qualifies him for nothing. "You know me, and you know where I am from" (Jn 7:28). But he then makes one of the central claims in all of the Gospel of John: "I have not come on my own ... but the one who sent me is true." Granted Jesus' biological origins are nothing, that he has no ascribed honor, yet in John's eyes that is irrelevant because Jesus does not come in his own name.

Note that forty-three times in John we are told that Jesus was "sent" by God. This is language that appears only twice in Matthew (10:40, 15:24), once in Mark (9:37), four times in Luke (4:18, 4:43, 9:48, 10:16) and once in Paul ( $\mathrm{Rm} \mathrm{8:3).} \mathrm{But} \mathrm{for} \mathrm{John} \mathrm{this}$ assertion that Jesus has been sent by someone higher (God) is the entire basis for his claim on people's attention. Jesus' place of origin is irrelevant because he claims absolutely nothing on his own. The relevant authority is the one who sent him.

The importance of this language about being "sent" can be seen in another way. In antiquity the "sent" messenger was one who came from a patron, a person of unquestioned stature and authority. As broker, the messenger's only claim to fame was access to the patron, nothing more. He simply acted as an intermediary between the patron and those for whom the patron's message or largesse was intended. This broker role is the one Jesus plays throughout John's Gospel. Note that eight times we are reminded that Jesus will return to his Patron (Jn 7:33, 13:1, 14:12, 28, 16:5, 10, 17, 28), suggesting that the broker has ready access to and from the Patron who sent him.

Readers of John's Gospel will not find it difficult to sense the defensive tone in all this. The sheer repetition of the claim that Jesus was "sent" is part of it. But so also are statements like, "The Father who has sent me has himself testified on my behalf. You have never heard his voice or seen his form, and you do not have his word abiding in you, because you do not believe him whom he has sent" (Jn 5:37-38). Our argument is thus that John's claim that Jesus is "sent" from God is intended as a defensive strategy meant to counteract the prevailing wisdom that one "from" Nazareth could claim no public standing on his own. John agrees that Jesus has no standing, but he claims that as broker for God Jesus bears the authority of his Patron.

One additional charge asserted by Jesus' Judean enemies may be added to all this. The typical instructions in the progynasmata (see above) remind a writer that after 
matters of origin and birth, the next conventional topic to be addressed when praising someone is the matter of nurture and education:

Next comes "nurture." Was he reared in a palace? Were his swaddling clothes robes of purple? Was he from his first growth brought up in the lap of royalty? ... If he does not have any distinguished nurture ... discuss his education, ... the quality of his mind. ... speak of his love of learning, his quickness, his enthusiasm for study, his easy grasp of what is taught him ... (Menander Rhetor, Treatise II.371.17-372.2)

John's Jesus would not qualify on this score either. Luke had provided at least a glimpse of Jesus' quickness and enthusiasm for study in the temple incident at twelve years of age (Jn 2:41-52). But nothing like this appears in John. In fact, in Jn 7:15, in the midst of a heated dispute in the temple, someone in the crowd raises an early challenge: "How does this man have such learning, when he has never been taught?" But once again Jesus' reply is typical of the strategy throughout the Gospel of John: "My teaching is not mine but his who sent me" (Jn 7:16). It is as if the writer knows he can make no claims for Jesus that will stand up before either his Judean opponents or potential readers of the account. Jesus had neither the proper origin nor the proper nurture/education. His recourse his thus to claim that Jesus was sent by God, speaks for God, speaks the words of God and makes no claim of his own for either his origin or his education.

In sum, unlike Luke who feels it necessary to move Jesus up the scale of honor to appeal to elite audiences, John's strategy is unique. He makes no claim for Jesus whatsoever. Everything ultimately comes from God; Jesus is simply the broker whom God has sent to speak on his behalf.

\section{IMPLIED SOCIAL RELATIONS}

This brief review of data from Luke and John reveals marked differences in rhetorical strategy. Luke buys into the logonomic system wholeheartedly. His behavior is constrained by the logonomic rules of elite Greco-Roman society and he apparently assumes his audience's expectations will correspond. In Luke, author, implied audience and no doubt real audience share a set of common assumptions and an obviously harmonious set of social relations as well. 
The case of John is somewhat more interesting. It is obvious that there are two audiences for Jesus in the story-world of the Gospel : opponents and those who are in the process of becoming members of Jesus' group. In the same way, there are parallel audiences among the potential readers of the Gospel : those with standard expectations, who look for typical signs of the honor of Jesus, and those who, like key characters inside the story, are in the process of becoming members of the Johannine community. For each of these groups, opponents and friends, both inside the story and outside among readers, John's narrative functions in a unique way.

For those open to Jesus, the Gospel offers many indications of the emerging glorification of Jesus. The prologue and the final chapters of the story anticipate and finally demonstrate how the heavenly honor of the less-than-honorable Jesus is being secured by the power of God. Since the Gospel is primarily meant to reassure new insiders that, in spite of all indications to the contrary, trust in Jesus is fully warranted, the many markers and portents of the heavenly glorification of Jesus are critically important. So also are key characters in the story-world (Nicodemus, the Samaritan woman, Mary; Thomas after the resurrection) who see the honor of Jesus before the hour of glorification actually comes. As they come to believe in him they model the experience the sympathetic reader must him/herself go through in joining the Johannine group.

But characters in the story-world who do not have this special insight, or are not really open to believing in Jesus, interact with him according to the usual norms of the honor-shame society. They look for the expected indicators of honor and find they are not there. Moreover, the same is true for those outside who read the Gospel expecting a strategy such as that in Luke. They too will see a Jesus who lacks the honor necessary to make him a significant figure.

It is clear that at the outsider level John assumes some in his audience will affirm the system and expect to be accommodated. Therefore both the opponent-audience of Jesus in the story-world and the implied outsider reading-audience he constructs for the Gospel share the expectation that he will have to present Jesus as honorific. John does not ignore these expectations, nor does he argue against their validity. He simply provides a rather strange way of meeting them. Since he cannot claim much for Jesus, he 
shifts the honor claim to God and makes Jesus the bearer of a delegated authority. Jesus is non-authoritative in his own right but becomes a broker who was "sent."

Two things are interesting here. One is that John does not challenge the system in a fundamental way. Just as much as Luke, he still needs to demonstrate an honorific basis for the authority of his message. If he cannot find it in Jesus, he finds it in God. At one level, therefore, John's behavior remains constrained by the same system of rules that energized Luke. We must be quick to point out, however, that John is less at home in this world than Luke and more at a distance from both the implied and real audiences he must accommodate and persuade.

Even more interesting, however, is the fact that John's strategy is a good example of marked speech. John does something unexpected. One would not normally admit that the person being commended in a narrative is a dishonorable low-life who cannot speak on his own authority. Yet that is the implication when John shifts the locus of authority to God. As the portents and key characters in the story indicate, the Johannine Jesus will eventually be glorified, but that is only after he leaves this world; hence the narrator keeps reminding the reader that the hour for this has not yet come (Jn 2:4; 7:30; 8:20). Until it does, John leaves the earthly Jesus beneath the threshold of honorific expectation.

It is clear that an ancient audience would notice what John is doing. Luke follows the normative pattern, but John does not. The audience might or might not buy into the notion of delegated authority and eventual glorification, but they surely would have found this a strange way to proceed. However by its very contravention of the expected way of claiming authority, John's narrative choice would have been an attention-getter, a marker. Just as a pause after a handshake draws attention to itself, so also does the radical shift in rhetorical strategy offered by John. Both are clear examples of marked speech.

John's strategy also implies social relations between author and the outsider audience quite different than those in Luke. Luke is comfortable with the conventions and assumes his audience is as well; hence he constructs a narrative along the expected lines. John knows the conventions, knows his audience will expect them, knows he cannot meet them; hence he creates a narrative the defensive tone of which belies a genuine strain in the social relations between John and those who hold the normal 
semiotic expectations. John's strategy is not that of someone comfortable in the world of Luke.

\section{CONCLUSION}

Space does not permit a full examination of the rhetorical strategies of each author in regard to the honor of Jesus. Luke especially employs a variety of strategies for moving Jesus up the scale of ascribed and acquired honor. But the illustrations we have examined warrant a tentative conclusion that while Luke buys into the logonomic system of the Greco-Roman elite with unhesitating enthusiasm, John is wary and guarded. He is prepared to contravene expectations with the full knowledge that his audience will be wary of the tactic. Thus in both Luke and John we can say that social relations and semiotic behavior correspond. Luke's social relations are harmonious. John's are not. Thus it is not just what they say, but how these authors choose to say it that demonstrates their respective stances toward both their audiences and a socially prescribed set of semiotic behaviors.

\section{Works consulted}

Abel, E L 1973. The genealogies of Jesus Ho Christos. New Testament Studies 20, 0310 .

Alexander, L C A 1986. Luke's preface in the context of Greek preface-writing. Novum Testamentum 28, 48-74.

Alexander, L C A 1993. The preface to Luke's Gospel. Cambridge: Cambridge University Press. (SNTS Monograph Series 79).

Alexander, L C A 1996. The preface to Acts and the historians, in Ben Witherington (ed), History, literature and society in the book of Acts, 73-103. Cambridge: Cambridge University Press.

Ashton, J 1991. Understanding the Fourth Gospel. Oxford: Clarendon Press.

Aune, D E 1988. Greco-Roman biography, in Aune, D E (ed), Greco-Roman literature and the New Testament: Selected forms and genres, 107-26. Atlanta: Society of Biblical Literature. 
Bernstein, B 1971. Class, codes and control, Vol I. London: Routledge/Kegan Paul.

Brown, R E 1977. The birth of the Messiah: A commentary on the infancy narratives in Matthew and Luke. Garden City, NY: Doubleday.

Brown, R E 1970. The Gospel according to John. Garden City, NY: Doubleday.

Brown, R E 1979. Community of the beloved disciple. Mahwah, NJ: Paulist.

Burridge, R 1992. What are the Gospels? A comparison with Greco-Roman biography. Cambridge: Cambridge University Press.

Caird, G B 1963. The Gospel of St Luke. New York: Seabury.

Campbell, J K 1964. Honour, family and patronage. Oxford: Oxford University Press.

Creed, J M 1942. The Gospel according to St Luke. London: MacMillan.

Drury, J 1976. Tradition and design in Luke's Gospel . Atlanta: John Knox.

Elliott, J H 1987. Patronage and clientilism in early Christian society. Forum 3(4), 3948.

Esler, P F 1987. Community and Gospel in Luke-Acts: The social and political motivation for Lucan theology. Cambridge: Cambridge University Press.

Esler, P F, (ed) 1995. Modelling Early Christianity: Social-scientific studies of the New Testament in its context. London: Routledge.

Fitzmyer, J A 1981. The Gospel according to Luke (I-IX). New York: Doubleday.

Fitzmyer, J A 1985. The Gospel according to Luke (X-XXIV). New York: Doubleday.

Fowler, R 1981. Language as social discourse. Bloomington, IN: Indiana University Press.

Fowler, R, Hodge, R, Kress, G R \& Trew, A 1979. Language and control. London: Routledge/Kegan Paul.

Gamson, W A 1992. The social psychology of collective action, in Morris, A D \& McClurg Mueller, C, (eds), Frontiers in social movement theory, 53-76. New Haven: Yale University Press.

Gellner, E \& J Waterbury 1977. Patrons and clients in mediterranean societies. London: Duckworth.

Giles, $\mathrm{H}$ et al 1987. Speech accommodation theory: The first decade and beyond, in McLaughlin, M L (ed), Communication Yearbook 10, 13-48. Beverly Hills, CA: Sage. 
Giles, H \& Scherer, K (eds) 1979. Social markers in speech. Cambridge: Cambridge University Press.

Giles, H \& Wiemann, J M 1987. Language, social comparison and power, in Berger, C R \& Chaffee, S H, (eds), Handbook of communication science, 350-384. Beverly Hills: Save Publications.

Gilmore, D D 1987. Honor and shame and the unity of the Mediterranean. A special publication of the American Anthropological Association. Washington DC:

Gramsci, A 1971. Selections from prison notebooks. New York: International.

Halliday, M A K 1971. Learning how to mean: Explorations in the functions of language. London: Edward Arnold.

Halliday, M A K 1976. Antilanguages. American Anthropologist 78, 570-84.

Halliday, M A K 1978. Language as social semiotic: The social interpretation of language and meaning. London: Edward Arnold.

Holub, R C 1984. Reception theory: A critical introduction. London/New York: Methuen.

Hodge, R \& Kress, G 1988. Social Semiotics. Ithaca, NY: Cornell University Press.

Hood, R T 1961. The genealogies of Jesus, in Wikgren, A (ed), Early Christian origins: Studies in honor of H R Willoughby, 1-15. Chicago: Quadrangle Books.

Hymes, D 1974. Foundations of sociolinguistics: An ethnographical approach. Philadelphia: University of Pennsylvania Press.

Jameson, F 1980. The political unconscious: Narrative as a socially symbolic act. London: Meuthen.

Jauss, H R 1974 Literary history as a challenge to literary theory, in Cohen, R (ed), New direction in literary history, 127-164. Baltimore: Johns Hopkins University Press.

Johnson, M D 1969. The purpose of the Biblical genealogies with special reference to the setting of the genealogies of Jesus. Cambridge: Cambridge University Press. (SNTS Monograph Series 8.)

Kennedy, G A 1963. The art of persuasion in Greece. Princeton, NJ: Princeton University Press.

Kennedy, G A 1972. The art of rhetoric in the Roman world. Princeton: Princeton University Press. 
Kennedy, G A 1984. New Testament interpretation through rhetorical criticism. Chapel Hill, NC: University of North Carolina Press.

Kress, G R 1987. Textual matters: The social effectiveness of style, in Birch, D \& O’Toole, M (eds), Functions of style, 39-59. London: Francis Pinter.

Kuper, A 1982. Lineage theory: A critical retrospect. Annual Review of Anthropology $11,71-95$.

Kysar, R [1976] 1993. John: The maverick Gospel. Revised edition. Atlanta: John Knox.

Malina, B J 1985. The Gospel of John in sociolinguistic perspective, in Herman Waetjen 48th Colloquy of the Center for Hermeneuitical Studies. Berkeley, CA: Center for Hermeneutical Studies

Malina, B J 1994. John's: the Maverick Christian group: Evidence from sociolinguistics. Biblical Theology Bulletin 24, 167-84.

Malina, B J 1988. Patron and client: The analogy behind synoptic theology. Forum 4(1), $2-32$.

Malina, B J \& Rohrbaugh, R L 1998. Social science commentary on the Gospel of John. Minneapolis: Fortress.

Marshall, I H 1978. The Gospel of Luke: A commentary on the Greek text. Grand Rapids, MI: Eerdmans.

Martyn, J L 1978. The Gospel of John in Christian history. New York: Paulist Press.

Miller, G R 1987. Persuasion, in Berger, C R \& Chaffee, S H (eds), Handbook of communication science, 446-483. Beverly Hills: Save Publications.

Neyrey, J H 1991 Honor and shame in Luke-Acts: Pivotal values of the Mediterranean World", in Neyrey, J H (ed), The social world of Luke Acts: Models for Biblical interpretation, 25-65. Peabody, MA: Hendrickson.

Perlman, C \& Olbrecht-Tyteca, L 1969. The new rhetoric: A treatise on argumentation, tr by J Wilkinson \& P Weaver. Notre Dame, IN: Univiversity of Notre Dame Press.

Petersen, N R 1993. The Gospel of John and the sociology of light: Language and characterization in the Fourth Gospel. Valley Forge, PA: Trinity Press International. 
Pitt-Rivers, J 1977. The fate of Shechem, or the politics of sex: Essays in the anthropology of the Mediterranean. Cambridge: Cambridge University Press.

Robbins, V 1991. The social location of the implied author of Luke-Acts, in Neyrey, J H (ed), The social world of Luke Acts: Models for Biblical interpretation, 305-332. Peabody, MA: Hendrickson.

Rohrbaugh, R L 1991. The pre-industrial city in Luke-Acts: Urban social relations, in Neyrey, J H (ed), The social world of Luke Acts: Models for Biblical interpretation, 125-149. Peabody, MA: Hendrickson.

Rohrbaugh, R L 2000. Gossip in the New Testament, in Pilch, J J (ed), Social scientific models for interpreting the Bible: Essays by the Context Group in honor of Bruce J Malina. Leiden: Brill.

Rosenfeld, L \& Civikly, J 1976. With words unspoken: The nonverbal experience. New York: Holt, Rinehart \& Winston.

Rush, O 1993. Reception hermeneutics and the "development" of doctrine. Pacifica 6, 125-140.

Saville-Troika, M 1982. The ethnography of communication: An introduction. Oxford: Blackwell.

Stibbe, M W G 1991. John. Sheffield: JSOT Press.

Stine, P C 1988. Sociolinguistics and Bible translation, in Stine, P C (ed), Issues in Bible translation, 146-172. New York: United Bible Societies. (UBS Monograph Series 3.)

Urban, G 1971. Review of language as social semiotic: The social interpretation of language and meaning, by M A K Halliday. American Anthropologist 83, 9-61.

Wallace-Hadrill, A, (ed) 1989. Patronage in ancient society. London: Routledge.

Wilson, R R 1975. The Old Testament genealogies in recent research. Journal of Biblical Literature 94, 168-89.

Yavetz, Z 1975. Reflections on Titus and Josephus. Greek, Roman and Byzantine Studies 16, 431-432. 